\title{
Quality of Life Improvement Model Related to Discharges Against Medical Advice (DAMA) Modulated by Mododuluan's of the Bolaang Mongondow Ethnic Group in North Sulawesi, Indonesia
}

\author{
Wiwit Ciptaningsih Haryanto ${ }^{1}$, Edi Widjajanto ${ }^{2}$, Jack Roebijoso ${ }^{3}$, Harsuko Riniwati ${ }^{4}$ \\ \{wiwitciptaningsiharyanto@gmail.com ${ }^{1}$, edwito.ew@gmail.com ${ }^{2}$, jackroebijoso@yahoo.com ${ }^{3}$, \\ riniwatisepk@gmail.com $\left.{ }^{4}\right\}$ \\ Universitas Brawijaya, Indonesia ${ }^{1,2,3,4}$
}

\begin{abstract}
DAMA (Discharge against Medical Advice) is an indicator of the lack of quality of hospital health services. DAMA among patients in general is caused by reduced faith or hope for recovery. One kind of approach that can raise hope for healing is through a cultural approach. A culture that is known in Bolaang Mongondow (Bolmong) is Mododuluan. Mododuluan is a form of mutual cooperation to help traditionally bequeathed ancestors. The purpose of this study is to obtain a model of improving quality of life in the context of controlling incidences of forced discharges using a cultural approach of the Bolmong community. This research is a quantitative research. The number of respondents was 156 patients. The study was conducted at Datoe Binangkang Bolmong Hospital in August 2019. The research variables were quality of life, DAMA, health insurance, and Mododuluan. Data was collected using copies of a questionnaire. Data was analyzed with SEM analysis using SmartPLS. The results showed that age, education, type of occupation, LOS, and quality of hospital services are indicators of DAMA. The most influential indicator was age. BPJS participation and general patients are indicators of health insurance. The most influential indicator was BPJS participation. Ethos of unity (Motobatu), ethos of cooperation (Mobobatungan), mutual improvement (Pogogutat), and mutual support are indicators of Mododuluan. The most influential indicator was ethos of unity. Physical functions, emotional functions, social functions, psychological welfare dimensions, and environmental dimensions are indicators of quality of life. The most influential indicator was social function. Mododuluan culture positively and significantly influenced quality of life, and quality of life and Mododuluan culture positively and significantly influenced DAMA. This study also showed that improvement of quality of life through DAMA was increased through Mododuluan culture, and DAMA through quality of life was decreased where Mododuluan was the strongest moderating variable. Mododuluan was the strongest moderating variable to improve quality of life in order to control the DAMA of patients from the hospital. Based on the results of this study, Mododuluan must be preserved
\end{abstract}

Keywords: Quality of life, DAMA, Mododuluan, Health Insurance, Bolaang Mongondow. 


\section{Introduction}

The Province of North Sulawesi has an area of $15,069 \mathrm{~km}^{2}$, consisting of 11 regencies and 4 cities. The majority of the population in North Sulawesi consists of the Minahasa, Bolaang Mongondow, Sangihe, Siau, Bajo, and Bantik tribes. Ethnic diversity makes North Sulawesi a multicultural area. Cultures present in North Sulawesi include Mapalus, Mododuluan, Masamper, Sasahara, and others. These cultures are to be maintained. Bolaang Mongondow Regency has a unique geotopography. Bolaang Mongondow has an area of $5,397 \mathrm{~km}^{2}$, a population of 233,189 people, and a population density of 43.2 people $/ \mathrm{km}^{2}$. Bolaang Mongondow has 1 hospital, 14 Puskesmas (community health centers), 141 Polindes (village childbirth centers), and 198 Posyandu (health service posts). These health facilities are considered lacking to serve the 233,198 residents of Bolaang Mongondow. Therefore, a study is needed on illness patterns in the area. The interest is to perform a cultural study concerning incidences of discharges against medical advice (DAMA) [1].

DAMA constitute an important issue to be studied with the implementation of BPJS, because home care is still not part of the service policy of BPJS. The phenomenon of DAMA continues to increase. In 2018, approximately $14.44 \%$ of patients were forced to leave. The facts and data about the phenomenon are quite remarkable, as an increase in DAMA occurs every year for various reasons and due to various backgrounds; the impact of forced discharge is thought to put a burden on individuals, families, the environment, and surrounding communities.

Quality of life, patient satisfaction, and patient health status can determine how "comfortable" a patient can feel during the Length of Stay (LOS) of their treatment, because LOS is largely determined by many factors such as the patient, the environment, costs, and service procedures. Quality of life can determine the length of stay of a patient. Patients having a better quality of life will have a higher level of comfort in a hospital. This can affect the incidence of DAMA during treatment at the hospital. DAMA is an indicator of the lack of quality of hospital health services. Patient DAMA in general is caused by decreased faith or hope for recovery. One kind of approach that can increase hope for healing is through a cultural approach. A culture that is known in Bolaang Mongondow is Mododuluan. Mododuluan is a form of mutual cooperation to help traditionally bequeathed ancestors. The purpose of this study is to obtain a model for improving the quality of life in the context of controlling the incidences of forced discharges using a cultural approach of the Bolaang Mongondow people.

\section{Research Method}

This research is a quantitative research. The utilized number of respondents was 156 respondents divided into case and control groups; the respondents for each group was determined as 78 respondents who were forced to leave for the case group and 78 respondents who were not forced to leave for the control group. The research was conducted at Datoe Binangkang Bolmong Hospital from August 2018-August 2019. The research variables are quality of life, DAMA, health insurance, and Mododuluan. Data was collected using copies of a questionnaire. Data was analyzed with SEM analysis using SmartPLS. 


\section{Results and Discussion}

\subsection{Mododuluan on Disasters and Death}

Mododuluan in this case occurred spontaneously as a form of solidarity among people in the event of disasters or deaths. When this happens, other people will spontaneously help the people affected by disasters. Whether or not they know the people in question, many people will come in droves to the homes of people affected by disasters to provide assistance.

The application of ethos and principles of Mododuluan in relation to forced discharges can be seen in the following table.

Table 1. Application of Mododuluan in health

\begin{tabular}{|c|c|c|}
\hline No. & Explanation & Application in health \\
\hline 1. & $\begin{array}{l}\text { Ethos of Brotherhood } \\
\text { (Pogogutat) }\end{array}$ & $\begin{array}{l}\text { Ethos of Brotherhood } \\
\text { (Pogogutat) } \\
\text { Have you ever been visited and supported by relatives, } \\
\text { friends, or other people in your neighborhood during } \\
\text { your illness? }\end{array}$ \\
\hline 2. & $\begin{array}{l}\text { Ethos of Kinship (Potolu } \\
\text { Adi) }\end{array}$ & $\begin{array}{l}\text { Ethos of Kinship } \\
\text { (Potolu Adi) } \\
\text { Do relatives, friends, or other people provide support not } \\
\text { to take a forced discharge (discharge from the hospital } \\
\text { before the doctor allows it)? }\end{array}$ \\
\hline 3. & $\begin{array}{l}\text { Ethos of Collaboration } \\
\text { (Mobobatungan) }\end{array}$ & $\begin{array}{l}\text { Ethos of Collaboration } \\
\text { (Mobobatungan) } \\
\text { When you are ill, do you have relatives, friends, or other } \\
\text { people who work together hand-in-hand if you need } \\
\text { help? }\end{array}$ \\
\hline 4. & $\begin{array}{l}\text { Ethos of Mutual } \\
\text { Cooperation (Momosad) }\end{array}$ & $\begin{array}{l}\text { Ethos of Mutual Cooperation } \\
\text { (Momosad) } \\
\text { When you are ill, do you have relatives, friends, or other } \\
\text { people who provide material assistance? }\end{array}$ \\
\hline 5. & $\begin{array}{l}\text { Ethos of Grace } \\
\text { (Mo'oruean) }\end{array}$ & $\begin{array}{l}\text { Ethos of Grace } \\
\text { (Mo'oruean) } \\
\text { When you are ill, do you have relatives, friends, or other } \\
\text { people who provide moral support for treatment and } \\
\text { recovery from the illness? }\end{array}$ \\
\hline 6. & $\begin{array}{l}\text { Ethos of Mutual Love } \\
\text { (Mototabian) }\end{array}$ & $\begin{array}{l}\text { Ethos of Mutual Love } \\
\text { (Mototabian) } \\
\text { Do you have relatives, friends, or other people who } \\
\text { provide support and motivation when you are ill? Do you }\end{array}$ \\
\hline
\end{tabular}




\begin{tabular}{|c|c|c|}
\hline & & $\begin{array}{l}\text { have great trust in them so that you can recover quickly } \\
\text { from the illness you suffered? }\end{array}$ \\
\hline 7. & $\begin{array}{l}\text { Ethos of Mutual } \\
\text { Improvement } \\
\text { (Mototompian) }\end{array}$ & $\begin{array}{l}\text { Ethos of Mutual Improvement } \\
\text { (Mototompian) } \\
\text { Do you have relatives, friends, or other people who } \\
\text { provide support and motivation when you are ill? Do you } \\
\text { have great trust in them so that you can recover quickly } \\
\text { from the illness you suffered? }\end{array}$ \\
\hline 8. & $\begin{array}{l}\text { Ethos of Unity } \\
\text { (Motobatu) }\end{array}$ & $\begin{array}{l}\text { Ethos of Unity } \\
\text { (Motobatu) } \\
\text { When you are ill, do you have relatives, friends, or other } \\
\text { people who are united in helping by taking turns to take } \\
\text { care of you? }\end{array}$ \\
\hline
\end{tabular}

\subsection{Relationship between Mododuluan and Pononibian}

Pononibian is not part of Mododuluan. Pononibian is a traditional medical ritual. The Mododuluan process begins with the motayok ritual, where relatives help each other to provide all the necessities for the ritual. The initial preparation involves costs, because the motayok ritual requires costs, particularly the cost of preparing food according to what the ancestors asked when they came to Bolian. To date, people still carry out this ritual. Generally, this is performed to treat patients who feel pain that they think is unusual, pain that cannot be treated medically, patients who feel pain but medical (laboratory) examinations show nothing, elderly patients aged 50 years and over, and patients who have been treated for a long time but has not recovered well [2].

Table 2. Cross tabulation of characteristics of individuals with forced discharges

\begin{tabular}{|c|c|c|c|c|}
\hline \multirow{2}{*}{\multicolumn{2}{|c|}{ Individual Forced }} & \multicolumn{2}{|c|}{ Discharge Individual Characteristics } & \multirow{3}{*}{$\begin{array}{c}\text { Total } \\
5\end{array}$} \\
\hline & & \multirow{2}{*}{$\begin{array}{c}\text { Yes } \\
3\end{array}$} & \multirow{2}{*}{$\begin{array}{l}\text { No } \\
2\end{array}$} & \\
\hline \multirow{10}{*}{ Age Group } & $5-7$ years & & & \\
\hline & $8-12$ years & 7 & 2 & 9 \\
\hline & 13-18 years & 5 & 19 & 24 \\
\hline & 19-25years & 9 & 23 & 32 \\
\hline & $26-35$ years & 5 & 14 & 19 \\
\hline & $35-45$ years & 15 & 9 & 24 \\
\hline & $46-55$ years & 16 & 5 & 21 \\
\hline & $56-65$ years & 8 & 2 & 10 \\
\hline & $>65$ years & 10 & 2 & 12 \\
\hline & Total & 78 & 78 & 156 \\
\hline \multirow{3}{*}{ Gender } & Male & 45 & 33 & 78 \\
\hline & Women & 33 & 45 & 78 \\
\hline & Total & 78 & 78 & 156 \\
\hline $\begin{array}{l}\text { Level of } \\
\text { Education }\end{array}$ & $\begin{array}{l}\text { Not completing } \\
\text { elementary school }\end{array}$ & 20 & 14 & 34 \\
\hline
\end{tabular}




\begin{tabular}{|c|c|c|c|c|}
\hline & $\begin{array}{l}\text { Graduated from } \\
\text { elementary school }\end{array}$ & 29 & 14 & 43 \\
\hline & Middle School & 13 & 21 & 34 \\
\hline & High school & 8 & 16 & 24 \\
\hline & $\mathrm{D} 1 / \mathrm{D} 2 / \mathrm{D} 3$ & 3 & 5 & 8 \\
\hline & $\mathrm{D} 4 / \mathrm{S} 1$ & 5 & 6 & 11 \\
\hline & $\mathrm{S} 2$ & 0 & 2 & 2 \\
\hline & Total & 78 & 78 & 156 \\
\hline \multirow{5}{*}{ Job type } & Not working & 31 & 25 & 56 \\
\hline & Private & 32 & 29 & 61 \\
\hline & Entrepreneurs & 11 & 9 & 20 \\
\hline & PNS/ TNI/ Polri & 4 & 15 & 19 \\
\hline & Total & 78 & 78 & 156 \\
\hline \multirow{3}{*}{$\begin{array}{l}\text { Length of } \\
\text { Stay (LoS) }\end{array}$} & 1-6 days & 54 & 65 & 119 \\
\hline & $>6$ days & 24 & 13 & 37 \\
\hline & Total & 78 & 78 & 156 \\
\hline \multirow{5}{*}{$\begin{array}{l}\text { Types of } \\
\text { Insurance }\end{array}$} & BPJS & 20 & 37 & 57 \\
\hline & KIS & 30 & 28 & 58 \\
\hline & Other insurance & 2 & 2 & 4 \\
\hline & General patients & 26 & 11 & 37 \\
\hline & Total & 78 & 78 & 156 \\
\hline \multirow{5}{*}{$\begin{array}{c}\text { Treatment of } \\
\text { Health }\end{array}$} & Health Service Facilities & 24 & 50 & 74 \\
\hline & Traditional alternatives & 41 & 3 & 44 \\
\hline & Modern Alternatives & 2 & 10 & 12 \\
\hline & Pononibian & 11 & 15 & 26 \\
\hline & Total & 78 & 78 & 156 \\
\hline
\end{tabular}

\subsection{Forced discharge and quality of life}

Forced discharge, or Discharge against Medical Advice (DAMA), is the termination of the contract of agreement between the provider (hospital) with the client in healthcare, disease prevention, health improvement, treatment of illness, and health recovery (Law No. 29 of 2004, Article 39). DAMA does not only occur in developing countries, but also in developed countries; for example, in Philadelphia in the United States, it was reported that the DAMA rate reached 5.3\%. Some publications also reported that DAMA accounts for $0.8-2.2 \%$ of total hospital discharges [3]. Other sources reported a DAMA rate of $0.57 \%$ and an average LOS of 2.8 days. A study in Baltimore showed that $1.0 \%$ of the total patients discharged incurred DAMA with an average LOS of 2.3 days. Similar publications also showed a DAMA prevalence of $0.34 \%$. This figure is lower compared to a study that reported a DAMA prevalence of 0.7 $7 \%$ for public hospitals. A retrospective analytic study of patient discharge registers at several Catalonia public hospitals reported a DAMA rate at the psychiatry department of Parc Taulí Hospital, Barcelona, of $0.34 \%$ of the total patients returning in a 2 -year period. The Internal Medicine Department of the same hospital recorded rates of $0.24 \%$ and $0.44 \%$ for the surgery department, $0.26 \%$ for bone surgery, $0.32 \%$ for obstetrics-gynecology, and $0.93 \%$ for rehabilitation. The average age of DAMA patients was 38.63 years and the majority were men, being $59.9 \%$. Of the total DAMA cases, $45.8 \%$ came from the Internal Medicine Department. DAMA requires attention because in addition to reducing the image of the hospital 
epidemiologically, it will also increase morbidity and potentially cause new problems for public health, as there are remaining health problems that have not been resolved and treatment programs that have not been completed. This means that if DAMA continues to occur and is not controlled, the social function of the hospital in improving the degree of public health will not be optimal. Another possibility that could occur is complaints that may appear at any time and possibly result in a claim toward the hospital if the forced discharge causes adverse outcomes, especially if the documentation is not good. DAMA rates at a hospital can also reflect failures in forming loyal customers [4].

DAMA is thought to be related to patient safety, which is a major component of service quality. This means that every medical action must be safe, as actions that are based on the latest and valid scientific evidence, carried out according to the best quality standards, and can ensure avoidance of the risk of medical claims by patients [5]. Forced discharges are one indicator of the lack of quality in health services because it can affect healing, costs, and so forth. Forced discharges are acts of stopping or revoking any action or treatment necessary to maintain human life so that the patient is expected to die after medical actions have been stopped, or actions of the patient to leave without the approval of the hospital that are taken when the patient does not understand advice from medical personnel. Forced discharge can worsen the health condition of a patient. The incidence of forced discharges is an indicator of inpatient services. In accordance with the minimum service standards of Ministry of Health Regulation No. 28 of 2008 , the number of forced discharges in hospitalization should be $<5 \%$ of all patients discharged within a certain period of time. Forced discharge is defined as patients that leave hospitals or other healthcare facilities before the doctor(s) who treat them allow them to leave. These forced discharge events are important because patients who are forced to leave before recovery and abandon their treatments in progress will have an effect on the perceptions of people regarding the hospital.

\subsection{Mododuluan and quality of life}

The research shows there was a shift in Mododuluan (mutual cooperation) cultural values in society, which can determine the quality of life of respondents. A study was conducted in Insil Village [6] on the factors that influence the shifting of Mododuluan cultural values in the society of Insil Village. The type of the research is a descriptive research with a qualitative approach by interviewing competent informants. The results of this study led to the conclusion that the cultural value of Mododuluan (mutual cooperation) in the society of Insil Village was still maintained and can also be found today, especially in societal activities in the form of Mododuluan agricultural activities, Mododuluan celebrations or marriage parties, and Mododuluan in events of calamities and deaths. However, as time progressed and interactions of the Insil Village society became wider, the Mododuluan cultural value became inseparable from the shift; several influencing factors, including the tidal factors of the economy of the Insil Village society, also influenced the shift in Mododuluan cultural values. Yet, the core of Mododuluan is voluntary work, and requires public awareness. Increased incomes of the people also contributed to the shift in Mododuluan cultural values. Another factor is the onslaught of modernization and outside culture. This is also supported by the succeeding generation of Insil youth, who are considered unable to maintain the traditions of the mogoguyang (ancestral) heritage.

Another research was conducted in Pinolosian Sub-District. The results of the study led to the conclusion that the Mododuluan tradition in Pinolosian had existed since the first arrival of the Pinolosian people; the Mododuluan tradition is a mutual cooperation tradition with 
historical value as the philosophy of life of the Pinolosian people that had been practiced since the time of the Bolaang Mongondow kingdom. Mododuluan tradition changes had occurred with the arrival of Europeans, such as the Portuguese and Spanish in the $16^{\text {th }}$ century, but the changes occurred only in procedures and not on philosophical values; changes also occurred due to the entry of Islamic influence in the $19^{\text {th }}$ century, which brought changes to procedures of implementation and the contained values.

\section{Conclusion}

Based on the measurement model for the Mododuluan variable above, it was found that the biggest item loading value was the ethos of unity (Y18), with $0.802(80.2 \%)$. This shows that the ethos of unity is the indicator that most influences Mododuluan. The influence of Mododuluan on quality of life resulted in a value of $\mathrm{p}=0.000$. This means that there is a modest effect on quality of life. Mododuluan culture positively and significantly influences the quality of life. Quality of life and Mododuluan culture positively and significantly affect forced discharge. Mododuluan culture is a strong mediator to increase the quality of life of patients and decrease forced discharge, and thus the culture needs to be preserved.

\section{References}

[1] I. Al Ayed, "What makes patients leave against medical advice?," J. Taibah Univ. Med. Sci., vol. 4, no. 1, pp. 16-22, 2009.

[2] W. Mokoginta, "Pergeseran Nilai Budaya Mododuluan (Studi Pada Masyarakat Desa Insil, Kecamatan Passi Timur, Kabupaten Bolaang Mongondow)," Skripsi, vol. 1, no. 231409072, 2013.

[3] H. Hwang, M.-H. R. Ho, and J. Lee, "Generalized structured component analysis with latent interactions," Psychometrika, vol. 75, no. 2, pp. 228-242, 2010.

[4] D. J. Alfandre, "I'm going home': discharges against medical advice," in Mayo Clinic Proceedings, 2009, vol. 84, no. 3, pp. 255-260.

[5] B. Muftau Jimoh et al., "Prospective evaluation of cases of discharge against medical advice in Abuja, Nigeria," Sci. World J., vol. 2015, 2015.

[6] D. Tungkagi, Membaca kembali Bolaang Mongondow (Renungan Masa Lalu, Kini dan Nanti). Jakarta: Oase Pustaka, 2017. 